\title{
7
}

\section{Ethnicity Based Immigration Checks}

\author{
Crimmigration and the \\ How of Immigration and Border Control*
}

MAARTJE VAN DER WOUDE

\section{Introduction}

Amidst the global Coronavirus pandemic, countries are taking far-reaching measures in trying to protect the nation state and its members. Within the European Union, Member States are taking different approaches when it comes to curbing mobility and thus potentially preventing the virus from spreading: some have fully 'closed' their intra-Schengen and external borders, which means that no one gets in without being checked at the physical border and that those who cannot prove to have a reason to be in the country will be refused entry, whereas others have implemented an entry-ban for people travelling from certain countries that are considered to be COVID-19 high risk areas. ${ }^{1}$ The latter means that the borders are still 'open' for those travelling from non-risk countries. At the time of writing this chapter, Germany, France and Belgium for instance have fully closed their borders, whereas the Netherlands and some other countries have taken the other approach. Making decisions about who is allowed to enter and who is not because they might be a potential risk seems to be more crucial than ever. These decisions on how to assess whether or not a person should be allowed to enter into a country tie in to a large, critical, body of scholarship on profiling and risk assessments. Whereas it seems rather clear cut that in trying to prevent people to further spread COVID-19 throughout Europe risk indicators would be based on various aspects of someone's health: does the person appear to be sick, are they coughing, do they have a fever etc, finding indicators to guide this process of decision-making in the context of immigration and border control in non-pandemic times seems to be more challenging. This is illustrated by a court case that was filed against the

\footnotetext{
* This work is part of the 5-year research project "Getting to the Core of Crimmigration" (project number 452-16-003), which is financed through the VIDI research scheme by the Dutch Science Council (NWO). The author is project coordinator and principal investigator.

${ }^{1}$ See for instance: https://euobserver.com/coronavirus/147742.
} 
Royal Netherlands Marechaussee (RNM) early 2020 by human rights organization Amnesty International, the lawyers for human rights committee NJCM and two Dutch people who claim to have been checked repeatedly on entering the Netherlands because of the colour of their skin. ${ }^{2}$ A case that, although it focuses on the Netherlands and the Royal Netherlands Marechaussee, might have significant implications for the ways in which border agencies across the EU make their decisions on whom to stop and check.

The RNM is a paramilitary organisation responsible for, amongst many other things, the implementation of the Schengen Borders Code (SBC). This means that they are tasked with carrying out border checks at the external borders of the Netherlands - which is mostly at the international airports and ports - but they are also tasked with the monitoring of the intra-Schengen borders based on article 23 of the SBC. ${ }^{3}$ Based on this provision and a limited but rather vast line of jurisprudence coming from the Court of Justice of the EU (CJEU), European Member States are allowed to carry out immigration control or crime control checks in a spatially designated area around the physical border. Yet, these checks have to meet certain requirements to prevent them from in reality being actually a hidden form of border control. That the latter seems to be a matter of semantics will be discussed more in depth later on, as research has shown that, especially in times of perceived or actual 'crisis', the notion of 'open' borders in Europe is, and has always been, rather relative. ${ }^{4}$ As already alluded to, another aspect that has always been strongly questioned by scholars and NGOs is the way in which, at the border but also more in general, decisions to stop and check are largely, and perhaps even predominantly, based on racial stereotypes and therewith a form of (in)direct discrimination. In the case that was filed against the RNM, Amnesty International and the NJCM claim that ethnicity as a selection criterion is discriminatory and not based on any objective or justifiable grounds. The RNM admit that ethnicity forms part of its controls, which are aimed at combating illegal immigration, passport fraud and human trafficking but denies it is the only reason to stop people. By bringing together literature on ethno-racial profiling and crimmigration as well as insights from ethnographic fieldwork done with the RNM, this chapter will address the question to what extent it is possible and also desirable for agencies tasked with the implementation of article 23 SBC checks to

\footnotetext{
${ }^{2}$ See Amnesty International's press release from 26 Feb 2020: www.amnesty.nl/content/ uploads/2020/02/Press-Release_Dutch-border-police-in-court-for-ethnic-profiling.pdf?x10542.

${ }^{3}$ Regulation (EU) 2016/399 of the European Parliament and of the Council of 9 March 2016 on a Union Code on the rules governing the movement of persons across borders (Schengen Borders Code).

${ }^{4} \mathrm{R}$ Bueno Lacy and H van Houtum, 'Lies, Damned Lies and Maps: The EU's Cartopolitical Invention of Europe' in A Cooper (ed), Where are Europe's New Borders?: Critical Insights into Contemporary European Bordering (Abingdon, Routledge, 2017); Adam K Webb, 'When Open Borders Must Stay Open: Expectations and Freedom of Movement' (2019) 51(2) Polity 202-30; Desmond Dinan, 'Debating Europe's Future' (2019) 34(4) Irish Political Studies 490-506; S Mau, H Brabandt, L Laube and C Roos, Liberal States and the Freedom of Movement: Selective Borders, Unequal Mobility (Basingstoke, Palgrave Macmillan UK, 2012).
} 
not, partially, base their decision to stop people based on their (perceived) ethnicity and/or race. In so doing, the article will also further elaborate upon Weber and McCulloch's observation that the crimmigration thesis is especially useful in understanding the how of immigration and border control. ${ }^{5}$

\section{Europe's 'Open’ Borders}

The differences between the MS in their responses to the Corona crisis are illustrative for the different ways in which MS have managed cross-border mobility within the Schengen Area even before the crisis. While the so deeply cherished and often lauded principle of free movement has always proven to be problematic and to trigger nationalistic tendencies and measures when it comes to the free movement of people, it is just in times of crisis when the tension that surrounds the principle becomes painfully clear. The so-called European migration crisis brought to the fore the fundamental lack of EU solidarity and absence of a collective response to the humanitarian and political challenges imposed by the influx. It also further laid bare the limitations of common border control and migration and refugee burden-sharing systems that had never been wholly and satisfactorily implemented. ${ }^{6}$ Nevertheless, it is important to realise that other than what is often thought or imagined, especially by a non-European audience, the implementation of the Schengen Agreement was never meant to deprive countries from all forms of border management: the true 'free' movement of people was seen as too risky in the light of the national security of the Member States. Therefore, from the very onset, the original Member States negotiated so-called compensatory measures: measures that were implemented to counter the risk(s) posed by doing away with permanent intra-Schengen border checks. ${ }^{7}$ Besides the use of systems such as the Schengen Information System (SIS) or the European Dactylographic System (Eurodac) - systems used to collect and exchange (biometric) information on people travelling through or trying to enter into the European Union ${ }^{8}$ - the

${ }^{5} \mathrm{~L}$ Weber and J McCulloch J, Penal power and border control: Which thesis? Sovereignty, governmentality, or the pre-emptive state? Theoretical Criminology. Epub ahead of print 9 October 2018. Weber, L., \& McCulloch, J. (2019). Penal power and border control: Which thesis? Sovereignty, governmentality, or the pre-emptive state? Punishment \& Society, 21(4), 496-514. https://doi. org/10.1177/1462474518797293.

${ }^{6}$ KM Greenhill, 'Open Arms Behind Barred Doors: Fear, Hypocrisy and Policy Schizophrenia in the European Migration Crisis' (2016) 22(3) European Law Journal 317-32.

${ }^{7}$ TJM Dekkers, MAH van der Woude and JP van der Leun, 'Exercising Discretion in Border Areas: On the Changing Social Surround and Decision Field of Internal Border Control in the Netherlands' (2016) 2(4) International Journal of Migration and Border Studies 382-402.

${ }^{8}$ For more information on these systems: MJ Pedersen, 'The Intimate Relationship between Security, Effectiveness, and Legitimacy: a New Look at the Schengen Compensatory Measures (2015) 24(4) European Security 541-59. 
Schengen Borders Code ${ }^{9}$ also made clear that MS would still have a way to monitor their intra-Schengen border regions. True, as a result of article 20 SBC, '[i]nternal borders may be crossed at any point without a border check on persons, irrespective of their nationality, being carried out', yet article $23 \mathrm{SBC}$ reads:

'The abolition of border control at internal borders shall not affect the exercise of police powers by the competent authorities of the Member States under national law, insofar as the exercise of those powers does not have an effect equivalent to border checks.

Article 23 thus allows countries to exercise police powers - and to carry out identity and immigration checks in intra-Schengen border zones - as long as: (1) the exercise of these powers cannot be considered equivalent to the exercise of border checks, (2) the police measures do not have border control as an objective, (3) are based on general police information and experience regarding possible threats to public security and aim, in particular, to combat cross-border crime, and lastly (4) as long as the measures are devised and executed in a manner clearly distinct from systematic checks on persons at the external borders and are carried out on the basis of spot-checks. ${ }^{10}$

\section{A. Autonomous Member States}

When looking at article $23 \mathrm{SBC}$ through a legal lens, it is clear that the article provides Schengen Member States a lot of discretionary space in how to actually implement and use the article within their national borders. Of course, at face value there seem to be some limitations put in place as to how these checks can be performed, but without the presence of a strong and functional objective and effective monitoring system, Member States still have a lot of autonomy when it comes to performing so-called 'article 23 ' checks. ${ }^{11}$ In terms of 'checks and

\footnotetext{
${ }^{9}$ Regulation (EU) 2016/399 of the European Parliament and of the Council of 9 March 2016 on a Union Code on the rules governing the movement of persons across borders (Schengen Borders Code).

${ }^{10} \mathrm{MAH}$ van der Woude, 'Border Policing in Europe and Beyond: Legal and International Issues' in M den Boer (ed), Comparative Policing from a Legal Perspective (Cheltenham, Edgar Elgar Publishing, 2018) 255-71.

${ }^{11}$ The objectivity and effectiveness of the new and the old 'Schengen Evaluation system' has been contested by several authors and institutions e.g., European Parliament's Policy Department for Citizen's Rights and Constitutional Affairs, Internal border controls in the Schengen area: is Schengen crisis-proof? European Parliament Study for the LIBE committee. Research Administrator D Neville, 2016; E De Capitani, 'The Schengen System after Lisbon: from Cooperation to Integration (2014) 15(1) Academy of European Law (ERA) Forum 101-18; Y Pascouau, 'The Schengen Governance Package: the Subtle Balance between Community Method and Intergovernmental Approach' European Policy Centre, Discussion Paper, 2013; MAH van der Woude and P van Berlo, 'Crimmigration at the Internal Borders of Europe? Examining the Schengen Governance Package' (2015) 11(1) Utrecht Law Review 61-79. For a pilot study on the effectiveness and the objectivity of the SES see: J Kaasik and S Tong, 'The Schengen Evaluation Mechanism: Exploring the Views of Experts in the Field of Police Cooperation' (2019) 18 European Law Enforcement Research Bulletin 53-69.
} 
balances', over the years, the discretionary space - or room for interpretation left in the wording of article $23 \mathrm{SBC}$ - has also been discussed by the CJEU in several cases against Germany, France and the Netherlands. ${ }^{12}$ This limited line of case law shows that the CJEU seems to follow a rather clear and strict line of reasoning by consistently stating that the national framework that Member States use to act in line with article $23 \mathrm{SBC}$ must 'guide the discretion that national authorities enjoy in the practical application of their powers' and prevent these checks from being a 'veiled' form of permanent border control and therewith explicitly at odds with the principle of free movement. The CJEU further states that the checks should be carried out randomly and based on 'general police information' and 'experiences regarding possible threats to public security' and in so doing repeating the wording of the SBC. It is therefore safe to say that both on the legislative level - the wording of the Schengen Borders Code - as well as on the level of the judiciary there doesn't seem to be the tendency to want to be more clear about the conditions under which article 23 checks can be carried out: the conditions remain very open and rather vague and leave room for narratives of the unwanted and potential dangerous or criminal 'other' to play a role in street-level decision-making in these border areas. And, as will be discussed in section III, it is precisely at this level - the street level - where discretionary decisions can play a crucial role in the process of crimmigration.

\section{B. Intra-Schengen Crimmigration Assemblages}

It is interesting to see that whereas there is a lot of research addressing the discretionary powers of law enforcements agencies operating within the borders of a nation state as well as an ever growing body of empirical research on crimmigration, the research on the discretionary powers of border officials - let alone on article 23 checks specifically - is rather limited still. ${ }^{13}$ This is of course understandable as the type of research that it would require to really observe and unravel how decisions are being made, qualitative fieldwork for a longer period of time,

\footnotetext{
${ }^{12}$ CJEU 19 July 2012 C-278/12 Adil, ECLI: C: 2012:508 (against the Netherlands); CJEU 22 June 2010, C-188/10 Melki \& Abdeli, ECLI: C: 2101:363 (against France); CJEU 21 June 2017, C-9/16, ECLI:EU:C:2017:483 (against Germany).

${ }^{13}$ With the exception of: K Côté-Boucher, 'The Paradox of Discretion: Customs and the Changing Occupational Identity of Canadian Border Officers (2015) British Journal of Criminology 1-19; Sara Casella Colombeau, 'Policing the Internal Schengen Borders - Managing the Double Bind between Free Movement and Migration Control' (2017) 27(5) Policing and Society 480-93; Irene I Vega, 'Empathy, Morality, and Criminality: the Legitimation Narratives of US Border Patrol Agents' (2018) 44(15) Journal of Ethnic and Migration Studies 2544-61; A Amenta, Protect, Serve, and Deport The Rise of Policing as Immigration Enforcement (Berkeley, University of California Press, 2017); A Pratt, 'Between a Hunch and a Hard Place: Making Suspicion Reasonable at the Canadian Border' (2010) 19 Social \& Legal Studies 461-80; A Pratt and SK Thompson, 'Chivalry, Race and Discretion at the Canadian Border' (2008) 48 British Journal of Criminology 620-40.
} 
would require a level of access that many border agencies would not feel comfortable allowing. In an attempt to nevertheless get a little bit more clarity about what various EU countries are doing in their border areas with either Schengen or non-Schengen states, in June 2018 a brief survey was launched with the help of the Dutch National Contact Point (DNCP) of the European Migration Network (EMN). ${ }^{14}$ Countries in principle have the obligation to respond to a so-called query sent by the EMN and there is also a financial compensation once a response is submitted, which should incentivise European Member States to react. Out of the 27 countries that the European Union is made up of, 21 countries responded. The six question-long survey questioned the Member States about Intra-Schengen border monitoring and border control, with the aim to provide a first insight into the extent to which the 'law in the books' - the Schengen Borders Code - resulted in similarities or differences between the 'law in action' in the different countries. The survey, among other things, shows that all countries that responded, as far as they were Schengen signatories, are indeed doing 'something' in their intra-Schengen border zones. ${ }^{15}$ This immediately illustrates the false premise of free movement in the Schengen area. The EMN data reveal considerable variety in the institutional arrangements related to border policing and immigration control. Criminal justice and immigration elements form a number of assemblages in the various countries. ${ }^{16}$ These arrangements are marked by a growing intersection between immigration control and criminal justice termed by Bowling and Westenra, ${ }^{17}$ Guia et $\mathrm{al}^{18}$ and Stumpf ${ }^{19}$ as 'crimmigration control'. This is clearly reflected by the described aim of the different bordering practices that are being deployed. All countries report that the measures are driven by a logic of risk for national security and the prevention of crime and irregular migration. With an increased pressure on the external borders of the European Union, countries - especially those who can be seen as so-called destination countries - are feeling the pressure to more closely monitor their intra-Schengen border zones. In justifying their action they actively adopt a language of risk and develop rhetorical campaigns based on fear, such as the 'war on terrorism' or the 'war on migration', in order to

\footnotetext{
${ }^{14}$ A summary of the findings of the query can be found at the website of the EMN: https:// ec.europa.eu/home-affairs/sites/homeaffairs/files/2018.1303_-_intra-schengen_border_monitoring and_border_control.pdf.

${ }^{15}$ The countries that responded were: Austria, Belgium, Croatia, Cyprus, Czech Republic, Estonia, Finland, Germany, Hungary, Italy, Latvia, Lithuania, Luxembourg, Netherlands, Poland, Slovak Republic, Slovenia, Sweden, United Kingdom, Norway.

${ }^{16}$ KF Aas, 'The Ordered and the Bordered Society: Migration Control, Citizenship and the Northern Penal State' in KF Aas and M Bosworth (eds), The Borders of Punishment: Migration, Citizenship and Social Exclusion (Oxford, Oxford University Press, 2013) 21-39.

${ }^{17}$ B Bowling and S Westenra, 'Racism, Immigration and Policing' in M Bosworth, A Parmar and Y Va'zquez (eds), Race, Criminal Justice and Migration Control: Enforcing the Boundaries of Belonging (Oxford, Oxford University Press, 2017) 61-77.

${ }^{18} \mathrm{MJ}$ Guia, M van Der Woude and J van Der Leun (eds), Social Control and Justice: Crimmigration in the Age of Fear (The Hague, Eleven International Publishing, 2013).

${ }^{19}$ J Stumpf, 'The Crimmigration Crisis: Immigrants, Crime and Sovereign Power' (2006) 56(2) American University Law Review 367-419.
} 
foster the securitisation of national and transnational spaces and to provide an enduring excuse for ethno-racial othering and the potential violation of European rules and regulations. ${ }^{20}$

\section{The Securitization of Migration and 'Open' Borders in the European Union}

The strong language of risk, prevention and precaution that was visible in the answers to the EMN survey fits in seamlessly with a broader trend that has been visible within criminal justice for the past decades. Scholars have voiced their concerns about the rise of the preventative state and the development of a culture of control in which actuarial risk assessments and preventative and proactive coercive powers are used to manage rising fears and concerns about crime. ${ }^{21}$ Both types of powers are meant to reduce (potentially) harmful behaviour to a tolerable level and coercive in the sense that people are forced, or at least feel rationally pressured, to comply with them if they don't want to get into trouble. ${ }^{22}$ The difference between the two types of powers is that preventative powers usually require some degree of reasonable suspicion, whereas that is not the case for proactive powers. The latter are seen as powers that can be used at all times to 'check' whether people are obeying the rules. As a result of the growing securitisation of migration, these developments are no longer limited to the realm of criminal law and criminal justice, but also seeped into the realm of immigration law and even more broadly, immigration control and the management of mobility: in most countries proactive powers are used to check whether people in intra-Schengen border regions are carrying valid identification.

Securitisation theory has been proven very helpful to make sense of the shifts in the discourse on and the practice of migration and border control as the theory provides a powerful explanatory framework for understanding how security is a performative and intersubjective process between the securitising actor and the audience. In other words, securitisation theory has helped to understand how the mediatisation and politicisation of migration, mobility and borders feed into people's already existing fears and anxieties that things that are beyond their control. And what is more frightening than an unknown - in size - flow of unknown - in terms of their intention - people? The late German sociologist Ulrich Beck already mentioned that risk societies, societies that are preoccupied with the calculation and the prevention of risks, are by nature also scapegoat societies. ${ }^{23}$ By this he

\footnotetext{
${ }^{20} \mathrm{~J}$ McCulloch and J Tham, 'Secret State, Transparent Subject: The Australian Security Intelligence Organization in the Age of Terror' (2005) 38 Australian and New Zealand Journal of Criminology 400-15.

${ }^{21}$ A Ashworth and L Zedner, Preventive Justice (Oxford, Oxford University Press, 2014).

22 ibid, 6.

${ }^{23}$ U Beck, Risk Society Towards a New Modernity (London, Sage Publications Ltd, 1992).
} 
means that especially in those cases where it is very difficult to pinpoint a clear entity to hold responsible for a potential risk - or a feared risk - individuals and societies will automatically seek a scapegoat to bear the brunt of the fears and anxieties. Often the scapegoat will be a (group of) 'other(s)' that already stands out within society because of their difference(s) from the dominant population. These differences will often be differences along the lines of race, religion and class. ${ }^{24}$ When applying the lens of securitisation theory to the many discourses on migration and mobility in the context of the European Union, entwined linkages between crime and migration were - as mentioned earlier - already visible during the initial deliberations about the Schengen Agreement, but were only further intensified in the wake of a range of terrorist attacks in various European countries in the 2000s. ${ }^{25}$ The call to further fortify the external borders of the European Union only grew stronger and more urgent. In that sense it is understandable that when it became clear during the Arab Spring in 2011, and the migratory flows as a result of that, that Europe wasn't the 'fortress' it thought or hoped it would be, several Member States started to panic. In public and political discourse at the time constructed displacement flows from the Southern Mediterranean as an 'invasion' of Europe. ${ }^{26}$ Migrants' arrivals from Tunisia and Libya led to reinstating border checks and to a temporary suspension of French-Italian Schengen cooperation, with other countries following soon as the numbers of migrants from predominantly Syria, but also other countries in the horn of Africa, continued to grow. These concerns prompted Sweden, Germany, France, Denmark and Austria to suspend Schengen temporarily whereas other countries such as Slovenia and Austria have sought to block migration flows by building metal fences. Throughout the whole of Europe, forms of migration management have emphasised tightened border controls, patrolling and surveillance. ${ }^{27}$

Public discourses also play a vital role in the production of a securitized knowledge on migration. Public discourses provide a powerful vector for 'dramatizing' and 'performing' migration as a security threat. They moreover turn an 'emergency

\footnotetext{
${ }^{24}$ U Beck, 'The Terrorist Threat: World Risk Society Revisited' (2002)19(4) Theory, Culture \& Society $39-55$.

${ }^{25} \mathrm{~V}$ Mitsilegas, 'Border Security in the European Union: Towards Centralised Controls and Maximum Surveillance' in A. Baldaccini et al (eds), Whose Freedom, Security and Justice? EU Immigration and Asylum Law \& Policy (Oxford, Hart Publishing, 2007).

${ }^{26}$ A Barry, 'Europe's Dilemma: Immigration and the Arab Spring' Foreign Policy in Focus (25 May 2012), http://fpif.org/europes_dilemma_immigration_and_the_arab_spring/; $\mathrm{H}$ de Haas, 'Europe's tiny refugee burden: Putting the Libyan migration crisis into perspective' (13 April 2011), http:// heindehaas.blogspot.com/2011/04/europes-tiny-refugee-burden-putting.html.

${ }^{27} \mathrm{MAH}$ van der Woude, 'Euroskepticism, Nationalism, and the Securitization of Migration in the Netherlands' in R Koulish, MAH van der Woude (eds), Crimmigrant Nations: Resurgent Nationalism and the Closing of Borders (Chicago, Fordham University Press, 2020) 227-48; K Franko, MAH van der Woude and V Barker, 'Beacons of Tolerance Dimmed? Migration, Criminalization, and Inhospitality in Welfare States' in SKN Bendixsen and T Wyller (eds), Contested Hospitalities in a Time of Migration: Religious and Secular Counterspaces in the Nordic Region. Religion, Resistance, Hospitalities (RRH): Interpretation, Analysis, and Documentation (Abingdon, Routledge, 2019) 55-75.
} 
situation' shaped as such by policymakers into a consequential act ${ }^{28}$ with 'real life' implications for the public sphere. They also provide an enabling terrain on which policy agendas inimical to migrants' interests thrive. Public debates about whether refugee arrivals are a threat to societal security and identity have proliferated, leading to a concerning upsurge of nationalistic discourse and the election of politicians representing a discourse of nationalism, exclusion and racism. ${ }^{29}$ As Bosworth et al observe:

The high octane public and political debates over immigration, particularly in relation to asylum seekers have often been marked by emotionally and exclusionary use old racial, gendered and religious tropes. The deserving and the undeserving, the genuine and the bogus are elided in an exclusionary push justified by unbridled electoral and populist politics. ${ }^{30}$

As Fakhoury notes, although various European platforms have contested the depiction of migrants and refugees as a liability, ${ }^{31}$ a general receptiveness to 'uttering' migration as a security threat has been crucial to the securitisation move. Migrants are seen as a threat to societal security and bordering practices as an important defence mechanism to ensure the survival of national cultures. ${ }^{32}$ The so-called migration 'crisis' in Europe thus seems to have highlighted the ever present tension between the opportunities and the risks that are inherent to the openness that Europe, and in particular the Schengen area, aims to represent. The migration crisis has led to various kinds of mobilisations of the most regressive and reactionary features of 'Europeanness': the protection of the national or supranational territory, the protection of the European people - read white European $^{33}$ - as well as rejection of the non-European other.

\section{Crimmigration and the How of Immigration and Border Control}

Whereas the literature on the securitisation of migration aims to illustrate how the public and political discourse of migration has become so intermixed with the topic of crime, the literature on crimmigration highlights how this translates into

\footnotetext{
${ }^{28}$ Anna Triandafyllidou, 'A "Refugee Crisis" Unfolding: "Real” Events and Their Interpretation in Media and Political Debates' (2018) 16(1-2) Journal of Immigrant \& Refugee Studies 198-216.

${ }^{29} \mathrm{R}$ Koulish and MAH van der Woude (eds), Crimmigrant Nations: Resurgent Nationalism and the Closing of Borders (Chicago, Fordham University Press, 2020).

${ }^{30} \mathrm{M}$ Bosworth, K Aas and S Pickering, 'Punishment, Globalization and Migration Control: "Get Them the Hell Out of Here" (2018) 20(1) Punishment \& Society 34-53.

${ }^{31}$ Tamirace Fakhoury, 'Securitising Migration: The European Union in the Context of the Post-2011 Arab Upheavals' (2016)51(4) The International Spectator 67-79.

${ }^{32}$ S Sassen, Guests and Aliens (New York, New Press, 1999).

${ }^{33}$ U Linke, German Bodies: Race and Representation after Hitler (Philadelphia, University of Pennsylvania Press, 1999); DT Goldberg, 'Racial Europeanisation' (2006) 29(2) Ethnic and Racial Studies 331-64.
} 
concrete legal measures and legal practices. That being said, looking at scholarship on crimmigration, it is not always clear how and if authors precisely distinguish between the two phenomena. This is to be explained by the fact that the term 'crimmigration, ${ }^{34}$ although now widely used by scholars, still remains quite ambiguous and is also increasingly contested. ${ }^{35}$ In its broadest sense, it describes a postulated blurring or fusion of functional, normative and discursive barriers between crime control and immigration control. There are many typologies of this convergence, most of which have emerged from the USA, which will not be fleshed out in this chapter as there is ample scholarship out there that does so. In finding explanations for the blurring of criminal law and migration law, Stumpf - who coined the term in 2006 - argues that membership theory, as applied within the legal system, produces categories of excluded and included individuals defined on the basis of a 'decision maker's vision of who belongs'. The decision-maker's vision, and his or her subsequent decision based on that vision, is therefore key in driving the 'crimmigration apparatus'. It is therefore understandable that Motomura claims that the discretion to stop persons is the strongest driver behind the process of crimmigration, ${ }^{36}$ since it enables racial profiling and makes street-level officers responsible for funnelling immigrants into systems dealing with immigration crime or criminal violations. His assessment of the pivotal importance of streetlevel decision-making in the process of crimmigration is widely shared among scholars, who often link it to selectivity based on racial stereotypes. ${ }^{37}$ Although there are competing perspectives as to what discretionary decision matters most in driving the process of crimmigration, this chapter focuses on the implications of the earlier mentioned proactive discretionary decisions made by street-level border officials. ${ }^{38}$ When analysing the explanatory nature of the crimmigration perspective, Weber and McCulloch reached the conclusion that it is especially helpful in getting a better understanding of the mechanisms, or technologies, of immigration and border control: the how of immigration and border control. ${ }^{39}$ Weber and McCulloch see the development of 'crimmigration law' as answering this question and, while referring to Stumpf, observe that the creation of crimmigration laws and practices can be explained by referring to the fact that both criminal law and immigration law are exclusionary in nature and therefore together a potent combination

\footnotetext{
${ }^{34}$ Stumpf, above n 19.

${ }^{35}$ G Hudson, 'Does Crimmigration Theory Rest on a Mistake?' (2018) 4(4) International Journal of Migration and Border Studies 303-25.

${ }^{36} \mathrm{H}$ Motomura, 'The Discretion that Matters: Federal Immigration Enforcement State and Local Arrests and the Civil-Criminal Line' (2011) 58 UCLA Law Review 1819-58.

${ }^{37}$ CCG Hernandez, 'Creating Crimmigration' (2013) 6 Brigham Young University Law Review 1457-516; R Koulish, Immigration and American Democracy: Subverting the Rule of Law (New York, Routledge, 2010); TA Miller, 'Blurring the Boundaries Between Immigration and Crime Control After September 11th' (2005) 25(1) Boston College Third World Law Journal 81-123; Stumpf, above n 19.

${ }^{38} \mathrm{MAH}$ van der Woude and JP van der Leun, 'Crimmigration Checks in the Internal Border Areas of the EU: Finding the Discretion that Matters' (2017) 14(1) European Journal of Criminology 27-45.

${ }^{39}$ Weber and McCulloch, above n 5.
} 
to permanently cast out unwanted elements from societies. Yet, whereas this observation is very true, it seems to overlook the fact that it is through the conscious creation of discretionary space within the law(s) that this exclusionary effect gets to be executed. When thinking back to Motomura's statement on the role and impact of the creation of discretionary preventative and proactive powers for street-level officials in fuelling the process of crimmigration, the notion of discretion would deserve a more central role in arguing why the crimmigration thesis explains the how of immigration and border control. The importance of discretion is also highlighted by Sklansky who claims that crimmigration cannot be viewed separately from a broader trend of what he calls 'ad hoc instrumentalism. ${ }^{40}$ With this he means a way of thinking about the law and legal authorities in which formal distinction between legal domains is of secondary importance and government officials can simply choose the most effective instrument for solving a problem in each individual case. According to Sklansky, this way of thinking is strongly influenced by skepticism with regard to the necessity and possibility of limiting the discretionary decision-making power of street-level officials. Sklansky notes that such an instrumental approach to law is intrinsically linked to crimmigration. Due to the increasing intertwinement of criminal enforcement and immigration control, street-level officials have a broader spectrum of possibilities to stop or investigate a person, which increases their discretionary power. He mentions that street-level officials are increasingly equipped with a toolbox of legal instruments that they can use to deal with unwanted individuals, whether they are criminals or migrants. Given the instrumental considerations and the emphasis on effectiveness, enforcement this way not only takes on a strong ad hoc character but the procedural safeguards retire to the background as well. Furthermore, the many options available to enforcers can quickly lead to a lack of transparency, because 'this way, little or no insight is provided into the grounds on which individual street-level officers base their choices and decisions' and these officers often face little accountability for their actions as long as formal complaints are filed. ${ }^{41}$

The nature of proactive checks and powers as explained above as well as the absence of the necessity for there being a reasonable of suspicion, contribute to the possibility that other factors and stereotypes will consciously, or unconsciously, start to play a role in the decision-making process. The long standing line of literature on the way in which so-called 'street-level bureaucrats' deal with the challenges of their work - especially in the absence of clear rules and when having to act under quite some pressure and competing political, organisational and personal priorities - has proven that many factors other than the legal rules play a role in

\footnotetext{
${ }^{40}$ DA Sklansky, 'Crime, Immigration, and Ad Hoc Instrumentalism' (2012) 15(2) New Criminal Law Review 157-223.

${ }^{41}$ JP van der Leun, MAH van der Woude and S de Ridder, 'Crimmigratie in de Lage Landen: Smeltende Grenzen?' (2013) 11(3) Strafblad 221-28, 227.
} 
their decision-making processes. ${ }^{42}$ In their research on judicial decision-making, Tillyer and Hartley point to the fact that street-level officials - judges, prosecutors and police officials - tend to fall back on perceptual shorthands in their work, especially when having to make decisions under time pressure and based off of very little information. ${ }^{43}$ As another example of using stereotypes and mental shorthands when making decisions Steffensmeier and colleagues' focal concerns theory argues that in the absence of complete information or unlimited time to make decisions, judges develop a 'perceptual shorthand' based on prior experience and stereotypical attributions to compensate for the uncertainty present in court decisions (e.g., who is dangerous and who is not). ${ }^{44}$ These perceptual shorthands can furthermore be organised into three focal concerns. The three focal concerns are, the offender's blameworthiness and the degree of harm caused the victim, protection of the community, and practical implications of sentencing decisions. In the context of the previously described preventive turn within criminal justice but also in immigration and border control, a development that goes hand in hand with the creation and usage of more preventative and proactive powers based in an attempt to identify and contain risks and 'would be' risks as early as possible, the protection of the community is most likely to play the most dominant role in the decisions made by street-level border officials. This means that any conscious or (un)conscious (implicit) biases and/or preconceptions on what a 'would be' risk would look like will affect their daily decision-making processes and therewith impact the lives of those on the receiving end of these decisions. Based on a convincing line of international research into the decisions of police and judicial authorities, we know that shorthands can contribute to the development or maintenance of cognitive illusions due to the erroneous existence of certain ethnic, racial or national stereotypes. ${ }^{45}$ Since this is undeniably contra legem and highly problematic, in the context of migration and border control it might be a justified question how it is possible not to let a person's perceived race or ethnicity play a role in the decision to stop someone. This is clearly a very unpopular question to ask, but as will be illustrated by the case of the Netherlands, a key question: not just in the light of the pending court case against the Royal Netherlands Marechaussee, but also in the light of proactive immigration and border control in general.

\footnotetext{
${ }^{42}$ J Black, Managing Discretion (Unpublished manuscript, London School of Economics, 2001) (www.lse.ac.uk/law/people/academic-staff/julia-black/Documents/black21.pdf); P Hupe and M Hill, 'Positioning Street-Level Bureaucracy Research' in Research Handbook on Street-Level Bureaucracy (Cheltenham, Edward Elgar Publishing, 2019); K Hawkins, The Uses of Discretion (Oxford, Oxford University Press, 1992).

${ }^{43} \mathrm{R}$ Tillyer and RD Hartley, 'Driving Racial Profiling Research Forward: Learning Lessons from Sentencing Research' (2010) 38(4) Journal of Criminal Justice 657-65.

${ }^{44}$ D Steffensmeier, JT Ulmer and J Kramer, 'The Interaction of Race, Gender, and Age in Criminal Sentencing: The Punishment Cost of Being Young, Black, and Male' (1998) 36(4) Criminology 763-98.

${ }^{45}$ MA Alexander, The New Jim Crow: Mass Incarceration in the Age of Colorblindness (New York, The New Press, 2012); K Glover, Racial Profling. Research, Racism and Resistance (Plymouth, Rowman \& Littlefeld Publishers, 2009); CL Schneider, 'Police Power and Race Riots in Paris' (2008) 36(1) Politics and Society 133-59; P Quinton, 'The Formation of Suspicions: Police Stop and Search Practices in England and Wales' (2011) 21(4) Policing and Society 357-68.
} 


\section{The Dutch Approach Towards Article 23 SBC}

In finding an answer to this chapter's leading research question, in this section where the Dutch approach towards article 23 SBC will be discussed, data will be used from an elaborate case study that was carried out in the Netherlands. Between March 2013 and November 2015, a team of three researchers observed the daily practice of street-level officials from the Royal Netherlands Marechaussee who were tasked with performing article 23 SBC checks in the border regions with Belgium and Germany. During this period the research team collected observational data on the stop and checks of the vehicles - and the persons in them - they conducted informal and formal (focus group) interviews with street-level and management level officials working in the Royal Netherlands Marechaussee and analysed a broad variety of legal and policy documents. As the data collected as part of this unique field study has been discussed in a variety of international publications already, this chapter will partially draw from these previous publications. ${ }^{46}$

The Dutch have named the national law interpretation of Article 23 of the Schengen Borders Code 'Mobile Security Monitoring' (MSM) ${ }^{47}$ Based on article 50 of the Aliens Law (Vreemdelingenwet) and article 4.17a of the Aliens Decree (Vreemdelingenbesluit), the RNM has the authority to patrol in a 20 kilometre zone around the Dutch-German and Dutch-Belgian borders. In this 20 kilometre zone, people entering Dutch territory (either by plane, train or motor vehicle) can be asked for their identification papers as well as residence permits to establish their identity, nationality and legal status, without the necessity of there being any reasonable presumption of undocumented residence. The goal of the MSM is to combat irregular migration into the country as well as certain forms of cross-border crime such as human smuggling and identity fraud. As a result of two rulings of the Court of Justice for the EU - the Melki/Abdeli case and the Adil case - the frequency and intensity of the MSM have been limited. According to article 4.17 a section 4 , checks on the road can be carried out for six hours a day with a maximum of 90 hours a month. Limitations also apply to the number of trains and planes that can be checked on a daily and a monthly basis. According to the Court, the limitations that have been put in place are sufficient to guarantee that the practical exercise of the power to carry out identity controls in border areas did not have an effect equivalent to border checks.

\footnotetext{
${ }^{46}$ TJM Dekkers, Mobility, control and technology in border areas: Discretion and decisionmaking in the information age ( $\mathrm{PhD}$ Thesis, Leiden University, The Netherlands, 2019); MAH van der Woude, J Brouwer and TJM Dekkers, Beslissen in grensgebieden: een onderzoek naar het Mobiel Toezicht Veiligheid zoals uitgevoerd door de Koninklijke Marechaussee (Den Haag, Boom Criminologie, 2016); J Brouwer, Detection, Detention, Deportation. Criminal Justice and Migration Control through the Lens of Crimmigration (Den Haag, Eleven International Publishing, 2020).

${ }^{47}$ van der Woude and van der Leun, above n 38; MAH van der Woude and J Brouwer, 'Searching for "Illegal" Junk in the Trunk: Underlying Intentions of (Cr)Immigration Controls in Schengen's Internal Border Areas' (2017) 20(1) New Criminal Law Review 157-79.
} 


\section{Maartje van der Woude}

As mentioned, according to the applicable national legal framework, no reasonable presumption of illegal residence is required for stopping persons in the context of an MSM. ${ }^{48}$ Article 4.17a paragraph 2 of the Aliens Decree states that the MSM 'is conducted on the basis of information or experiential data on illegal residence after crossing the border'. There is no further specification of the nature of the information or experiential data, which creates considerable discretion for street-level RNM officers in the selection of persons and vehicles and therewith also a real risk of selection based on ethnicity and nationality. The previously mentioned research into the MSM has indeed shown that RNM officials, amongst other things, indeed base their decision to stop and pull over a car for inspection on the external characteristics of the occupants of the vehicle, but also on the licence plate as an indicator of nationality. ${ }^{49}$ To justify this, street-level RNM officers explain that both ethnicity and nationality are relevant indicators in the light of the central aim of the MSM: combating irregular migration into the Netherlands. Before discussing to what extent this justification holds ground, it is important to take a closer look into the 'law in action' based on the previously mentioned fieldwork.

\section{A. Targeting Irregular Migration ...}

The decision to select persons and vehicles for a check, as observed by the researchers, was usually made by an RNM officer on a motorcycle who selected 'interesting' vehicles just after the border. He or she then directed the vehicle to a control location further inland, where other officers carried out the actual control by checking the identity papers of the persons stopped. Other times officers would drive around in vehicles and carry out both the stop and the control themselves. Because traffic normally passed at high speed, officers frequently indicated there was very little opportunity for a thorough examination of the passing vehicles and its passengers. They had to decide within a split second whether to select a vehicle or not, some- times without a clear view of the passengers due to darkness or bad weather. Officers were therefore usually only able to see very basic features of the passengers, such as a beard, skin colour or certain clothing. They furthermore had little to no prior information on the vehicles that were passing. Although most shifts started with a briefing in which attention was paid to wanted persons, this information was often provided by the police and usually not so much related to illegal migration or migration-related offences. Officers repeatedly stated that they believed this would not be very useful anyway, as the realities on the street cannot

\footnotetext{
${ }^{48}$ Vreemdelingencirculaire 2013, A2/2.

${ }^{49} \mathrm{MAH}$ van der Woude, J Brouwer And TJM Dekkers, Beslissen in grensgebieden: een onderzoek naar het Mobiel Toezicht Veiligheid zoals uitgevoerd door de Koninklijke Marechaussee (Den Haag, Boom criminologie, 2016).
} 
be captured in formal training or written instructions. As one officer said, 'you really only learn it when you are at the workplace.' In general, officers relied on their own judgements about how to filter out potential unauthorised immigrants. Besides the nationality of the licence plate, the number of passengers and the state of the vehicle, they strongly relied on skin colour as a visible marker of 'foreignness' to detect potential unauthorised immigrants. Almost all RNM officers we met were white males and perceived non-whiteness as an important indicator of foreignness. In practice this meant that during our observations primarily black or Arab-looking people were stopped.

Over the course of the fieldwork, numerous stops were justified by officers on the basis that the vehicle looked rather old, was of a particular brand or had a foreign licence plate, in combination with the 'foreign appearance' of the driver and passengers. An interaction between one of the researchers and an officer that occurred during the observations can illustrate this. When the researcher asked the motor driver why he had selected a particular vehicle, he responded by asking whether the researcher had seen the licence plate. After the researcher saw that it was a Belgian licence plate, the officer asked him in a rhetoric tone whether he thought the two passengers - who had Arabic features - looked Belgian to him. The officer then continued by saying that of course it was possible they were, but that he was nonetheless curious to check, also because they came into the Netherlands from Germany in a vehicle with a Belgium licence plate. Whereas skin colour was thus an important factor behind immigration-related stops, sometimes other factors were employed to infer 'foreignness'. During one control, researchers were in a car with two officers after dark, when the officers decided to follow a vehicle with Dutch licence plates. As they had not been able to see inside the vehicle they checked the licence plate in the systems. When they heard that the vehicle was registered by someone with an African sounding name, the driver said 'that is a name we can work with' and decided to stop the vehicle for a check.

\section{B. ... Through Ethno-Racial Profiling? ${ }^{50}$}

Although most RNM officers were aware of the sensitivity of using racial or ethnic categories as a factor in their decisions and societal concerns about discrimination, they nonetheless often freely admitted that these categorizations played a role in their selection. As one of them said:

When people ask if we select on the basis of skin colour, then we have to readily admit that. Somebody's skin colour is for us the first sign of possible illegality. But, because we select on the basis of skin colour does not automatically mean that we discriminate.

\footnotetext{
${ }^{50}$ This section is based on an article that was previously published in Dutch: MAH van der Woude, TJM Dekkers and J Brouwer, 'Over crimmigratie en discretionair beslissen binnen het Mobiel Toezicht Veiligheid ... of Vreemdelingen ... of Veiligheid?' (2015) 14(2) Tijdschrift voor Veiligheid 19-35.
} 
Such openness was always coupled with a resolute denial that this selection criterion was driven by any racist intentions or motives. Instead, officers argued that their specific task of preventing illegal immigration leaves them little choice but to base their stops at least partially on skin colour as proxy of being a migrant. Indeed, they saw it as inherent to their work in the context of immigration law. Respondents emphasised their intentions rather than the outcomes. And as one officer explained:

It is also the fact that many of those countries have a visa requirement. Look, we did not invent the visa requirement for Africa. That by chance it is black people that come from there is not our fault, that is what we have to control, if there had been living only white people that had visa requirements we would have been checking white people.

Such statements are in line with Satzewich and Shaffir's argument that 'the occupational culture enables the police to draw upon a vocabulary of explanations [that] permits them to deny responsibility when faced with the allegations that their profiling is racially motivated. ${ }^{51}$ According to them these kind of rationalisations help officers deal with possible feelings of guilt or shame, and generally offer a better explanation for police behaviour than intentional racism.

At the political level, concerns with respect to potential discrimination during the MSM have continuously been countered with reference to professionalism. Officers are supposed to act on the basis of more objective criteria rather than solely rely on appearance. ${ }^{52} \mathrm{RNM}$ officers indeed regularly pointed out that stops were based on a combination of factors and not appearance alone. The origin of the licence plate, the number of passengers, their clothing, other appearancerelated factors and sometimes their behaviour were all factors that could play a role in the decision to stop a vehicle. In the debate on ethno-racial profiling there is disagreement about whether markers for ethnic categories are never allowed to play a role in decisions to stop, or whether it is acceptable when these markers are combined with other factors informing a decision. ${ }^{53}$ Such considerations were also found among RNM officers: 'Naturally we are here to find illegal immigrants, so somebody's appearance and skin colour are important factors. Of course these are not allowed to be the only factors, I also know that and I agree with that'. More elaborate combinations of factors were also presented. For example, one officer gave a more detailed description of how a combination of factors could be invoked to stop a vehicle with North-African looking persons, drawing on knowledge and ideas about illegal immigration patterns.

\footnotetext{
${ }^{51}$ V Satzewich and W Shaffir, 'Racism versus Professionalism: Claims and Counter-Claims about Racial Profiling' (2009) 51(2) Canadian Journal of Criminology and Criminal Justice 199-226, 231.

${ }^{52}$ TJM Dekkers and MAH van der Woude, 'Acceptance Denied: Intelligence-led Immigration Checks in Dutch Border Areas' (2016) 4(2) European Journal of Policing Studies 242-65.

${ }^{53}$ MR Smith, 'Depoliticizing Racial Profiling: Suggestions for the Limited Use and Management of Race in Police Decision-Making' (2004) 15 George Mason University Civil Rights Law Journal 219-60.
} 
You notice that we get a lot of cars from France, Spain, Italy, those are interesting for us. There are of course a lot of people from North-Africa, Algerians and Moroccans who don't have their documents straight. It is simply known that they often come here with family members illegally so if you see something like that coming it is just interesting. When it is somebody driving alone it is less interesting, but if it is several people with North-African appearance you make sure to stop it.

At the same time, it was somewhat contradictory that although licence plates were the main other indicator of 'foreignness', a relatively large number of vehicles that we observed being stopped had Dutch licence plates. During our observations it regularly seemed that a 'foreign appearance' was the primary or only reason for a stop, especially when vehicles had a Dutch licence plate. For example, one time an officer indicated he had stopped a vehicle because he had the feeling it was not right'. When asked if he could explain that feeling, he responded that 'those three guys [the passengers, MW]' had aroused his interest. After talking a bit more, it became clear that he found it striking that three men with, according to the officer, 'clearly non-Dutch facial features' were driving a vehicle with a Dutch licence plate.

\section{Crimmigrant Stereotypes ${ }^{54}$}

Although the MSM is primarily aimed at preventing illegal entry and stay, there is a lack of clarity about what exactly falls within the official aims RNM officers are also tasked with, combating 'migration related forms of crime. ${ }^{55}$ Although this ambiguity was rarely considered an issue by officers, who generally seemed more interested in fighting crime than controlling illegal immigration, it had a large impact on the factors influencing officers' decisions. The focus on crime resulted in different groups being targeted. Various RNM officers expressed the idea that 'Moroccan', or more generally 'North-African', young men were disproportionally involved in - especially drugs-related - crime. This resonates with the study of Bonnet and Caillault, who found that Dutch regular police officers were heavily concerned with 'Moroccans' being involved in criminal behaviour. ${ }^{56} \mathrm{RNM}$ officers pointed to arrest and prison statistics as concrete evidence of this overrepresentation. Thus while North-African looking people were regularly stopped because of potential illegal entry or stay, especially when their car had a foreign licence plate, officers also indicated a few times that a stop involving young Moroccan-looking

\footnotetext{
${ }^{54}$ This section is based on the article: J Brouwer, MAH van der Woude and JP van der Leun, '(Cr) immigrant Framing in Border Areas: Decision-Making Processes of Dutch Border Police Officers (2018) 28(4) Policing and Society 448-63.

${ }^{55}$ See more about this ambiguity: van der Woude and Brouwer, above $\mathrm{n} 48$.

${ }^{56} \mathrm{~F}$ Bonnet and C Caillault, 'The Invader, the Enemy Within and They-Who-Must-Not-Be-Named: how Police Talk about Minorities in Italy, the Netherlands and France' (2014) 38(7) Ethnic and Racial Studies 1-17.
} 
men was primarily based on crime-related reasons. A North-African background could thus be a factor in stops both related to migration control and crime control. However, in the Netherlands there is a large population with a Moroccan background that can no longer be seen as foreigners or immigrants. Instead, they are typically born in the country and hold Dutch citizenship; Moroccan is usually seen as an ethnic, rather than national, category. As such, the ambiguity about the exact aim of the MSM on a political and policy level translates into the targeting of groups that are not necessarily interesting in the context of what is supposed to be primarily an instrument of migration control.

Although North-African young men were regularly linked to various forms of crime, most commonly and openly associated with criminal behaviour were people from CEE countries - primarily Bulgarians and Romanians, to a lesser extent also Hungarians and Polish. Such perceptions were usually said to constitute 'known facts' and being based on 'evidence'.

I think that there is just evidence that if you say 'human trafficking', those are Bulgarians, it is just like that.

No but if a Romanian is driving a vehicle with an Italian license plate then you already know something is not alright. They drive through all of Europe to commit criminal offenses and that is also proven.

During the observations, a relatively large number of vehicles with Eastern European licence plates were stopped, and officers regularly indicated that a Bulgarian or Romanian licence plate was already sufficient reason for them to make a check. Although other Eastern European countries were sometimes also mentioned - in particular Albania - the relatively high number of vehicles from Poland, Bulgaria and Romania that drive to the Netherlands meant that they were most often stopped. The targeting of these groups was primarily based on the origin of the licence plate, as this was an easy visible marker and the nationality of individuals from Eastern European Member States are generally harder to recognise on the basis of physical characteristics. Nonetheless, officers said it was a particular challenge to also be able to select Eastern European people when they were driving a vehicle with another licence plate, something that regularly happened. For example, during one of the controls researchers were sitting in the back of the vehicle when a car with a German licence plate was stopped. According to the officer he had stopped the car because he believed the driver and passengers to be Albanian, and Albanians were often involved in crime in the Netherlands. Justifications for such stops were based on the merging of a variety of crime risks that range from mobility-related offences such as human trafficking and false identification papers to more mundane crimes as pickpocketing and theft.

That has to do with crime there. We have come across a lot of false documents from Romanians and Bulgarians, many false ID-cards and that is one of our priorities.

And the Bulgarians and the Romanians and especially the Bulgarians are known for false papers and Romanians too, but Romanians are also well known for pickpocketing etcetera, human trafficking. 
Overall, there was a common understanding among RNM officers that 'there is almost always something wrong' with members of these groups in the border areas concerned. This led to extreme statements proclaiming that nine out of 10 times Eastern European drivers have burglary tools in their trunk, or that Romanian looking people in a vehicle with a British or Spanish licence plate were nine out of 10 times thieves.

These 'profiles' were based on shared ideas rather than on information provided by the organisation. At the same time, it was interesting to note that such commonsense profiles were far from static. Nationalities that used to be targeted quite frequently could become less interesting over time, as during our research was the case with people from Poland. While Polish vehicles were considered interesting for various crime-related reasons in earlier years, respondents regularly stated that this was now much less the case. Although they were sometimes mentioned in the same breath with Bulgarians and Romanians, other times clear distinctions were made and it was argued that Polish people nowadays mostly came here to work and had their papers in order. As one officer noted: in the beginning we checked them quite a lot. Those vans and stuff. But it turns out that most of it is workrelated. That did not necessarily translate into practice though, as we still quite regularly observed Polish vehicles being checked during the controls. However, officers were now much less positive about the likelihood of actually encountering something wrong than they were in the past.

This normalcy of nationality as a proxy for a high risk background reflects the findings of Pratt and Thompson, ${ }^{57}$ who argued in their study on Canadian border officials that 'while race is an unacceptable basis of discretionary risk assessment at the border, nationality is continually reproduced as a legitimate consideration'. Dutch border police officers equally seemed to find that assumed nationality (often based on licence plates) was far less controversial as a (partial) selection criteria than ethnic or racial features, especially for crime-related stops.

\section{Ethnicity and Race as Problematic Indicators for Immigration Control? ${ }^{58}$}

The empirical insights presented in the previous section touch upon a complicated discussion about whether ethno-racial profiling is about intentions or outcomes and therewith also on the very core of the legal case that was filed against the Royal Netherlands Marechaussee. Obviously the practices that were observed in the research result in ethnic disparities among those who are stopped during the

\footnotetext{
${ }^{57}$ Pratt and Thompson, above n 13, 632.

${ }^{58}$ PR Rodrigues and MAH van der Woude, 'Proactieve politiecontrole en onderscheid naar etniciteit of nationaliteit; (2016) 91(32) Nederlands Juristenblad 2294-302.
} 
MSM and may send a message of non-belonging to the relatively large number of legal residents or citizens that are stopped on account of their 'foreign appearance. At the same time this does not directly mean that RNM officers are driven by beliefs about the inferiority of certain groups of people. Alpert et al note that certain organisational or legal factors 'can lead to discriminatory policing without individual-level discrimination. ${ }^{59}$ This seems particularly true for proactive forms of border policing aimed at preventing illegal immigration; it is the instrument that leaves individual officers little choice but to use their powers in a discriminatory way, with skin colour playing an important role.

Although it is understandable how race and ethnicity as well as proxies thereof - most importantly, licence plates - can play a role in discretionary decisions made by street-level officials tasked with immigration and border control, it is the question to what extent these factors are legally allowed to play a role at all in their decision-making.

Race as a legal concept is enshrined in the International Convention on the Elimination of All Forms of Racial Discrimination (ICERD). Article 1 paragraph 1 of the convention reads that race should also be understood to include skin colour, descent and ethnic or national origin. Nationality is excluded, although the treaty does prohibit discrimination against a certain nationality (Article 1, paragraph 3). Signatory States to the convention are in principle permitted to distinguish between nationals and foreign nationals (Article 1, paragraph 2). In addition, 'race' is mentioned in the non-discrimination clauses of, inter alia, the International Covenant on Civil and Political Rights (Article 26 ICCPR) and the ECHR (Article 14). Nationality is lacking as a ground for discrimination in these treaties, but this is covered by the jurisprudence on the open norm 'on any ground', as a result of which this form of discrimination also falls within the scope of the clause. ${ }^{60}$

A complicating factor is that European Union law applies to immigration and border control actions, which is the case with regard to the MSM as carried out by the RNM. Under EU law discrimination based on race and nationality is prohibited based on article 21 of the EU Charter. Furthermore, article 18 of the Treaty on the functioning of the European Union reads: 'Within the scope of application of the Treaties, and without prejudice to any special provisions contained therein, any discrimination on grounds of nationality shall be prohibited'. It is disputed whether this provision only concerns the protection of the nationality of EU nationals, because it can be argued that the provisions on border control (Article 77), asylum (Article 78) and regular residence and the prevention of illegal residence and human trafficking (Article 79) third-country nationals also

\footnotetext{
${ }^{59}$ GP Alpert, JM MacDonald and RG Dunham, 'Police Suspicion and Discretionary Decision Making During Citizen Stops' (2005) 43(2) Criminology 407-34.

${ }^{60}$ EHRM 16 september 1996, 17371/90 (Gaygusuz/Oostenrijk), NJCM-Bulletin. 1997, nr. 4, p. 461-474, m.nt. Groenendijk
} 
fall within the scope of Article 18 of the Treaty on the functioning of the European Union. ${ }^{61}$ Up until today, the CJEU has not yet ruled on this.

Also, a distinction needs to be made between direct and indirect discrimination. Direct discrimination is happening when someone is treated differently based on one of the so-called protected characteristics such as skin colour. ${ }^{62}$ Indirect discrimination is at play when a criterium is being applied in such a way that it is disproportionately disadvantageous for persons who are protected against direct discrimination. For example, if a disproportionately large number of cars with a Polish licence plate are stopped, this will predominantly affect Polish people. Indirect discrimination is sometimes used to disguise someone's actual intentions. In these cases, the CJEU speaks of 'disguised discrimination. ${ }^{63}$ Both under European Union law and under the various human rights treaties it is less likely for direct forms of discrimination to be justified than for forms of indirect discrimination. Under European Union law, such justification should lie in a legal exception and under the case law of the European Court of Human Rights (ECtHR) there is no objective justification for discrimination on ethnic grounds only in the case of disputed police actions. ${ }^{64}$ It is less likely to find justified exceptions for racial discrimination than for discrimination based on nationality. In addition to that, the CJEU tends to equate indirect racial discrimination based on unsubstantiated prejudice with direct racial discrimination. ${ }^{65}$ When it comes to objective justifications for indirect discrimination it has to be proven that the distinction is made in order to pursue a legitimate goal and that the means to achieve the goal must be appropriate and necessary.

It is therewith safe to conclude that it will be very difficult, if not impossible, to find an objective justification for direct discrimination based on race. This could be the case with indirect discrimination, as long as the indirectly discriminatory actions are not driven by stereotypical perceptions about certain populations. ${ }^{66}$ Making distinctions based on nationality can more easily be justified than distinctions based on race. The ECtHR states that it is necessary in these cases to prove that there were 'very weighty reasons' to do so. ${ }^{67}$ What is difficult to assess is the extent to which these characteristics - race and nationality - can play a role when they are part of a composed range of characteristics guiding a decision. There still seems to be some room for negotiation there, some discretionary space for the courts to further specify.

\footnotetext{
${ }^{61} \mathrm{E}$ Brouwer and $\mathrm{K}$ de Vries, 'Third-Country Nationals and Discrimination on the Ground of Nationality: Article 18 TFEU in the Context of Article 14 ECHR and EU Migration Law: Time for a New Approach' in M van der Brink, S Burri and J Goldschmidt (eds), Equality and Human Rights: Nothing But Trouble (Utrecht, Netherlands Institute of Human Rights (SIM), 2015) 139-41.

${ }^{62}$ Other protected characteristics are: Age, Disability, Gender, Marriage and civil partnership, Pregnancy and maternity, Religion and belief, Sex, Sexual orientation.

${ }^{63}$ HvJ EU 12 februari 1974, C-152/73 (Sotgiu), r.o. 11.

${ }^{64}$ EHRM 13 december 2005, 55762/00 en 55974/00 (Timishev/Rusland), r.o. 58.

${ }^{65}$ HvJ EU 16 juli 2015, C-83/14 (Chez), JV 2015/308, m.nt. Rodrigues.

${ }^{66}$ EHRM 24 mei 2016, 38590/10 (Biao/ Denemarken).

${ }^{67}$ EHRM 8 april 2014, 17120/09 (Dhahbi/Italië), r.o. 48.
} 
When looking at the specific goal of the MSM - preventing irregular migration into the Netherlands - it is clear that this goal is related to preconceptions of someone's legal status. Given the fact that the MSM is carried out in the form of spot checks in intra-Schengen Border areas, it seems very difficult to imagine how someone's perceived nationality or ethnicity cannot play a role in the decisionmaking process in combination with less problematic factors such as someone's behaviour, the looks of the car, etc. Contrary to the racial profiling of potential 'criminals' by the regular police, one could argue that taking into account the characteristic(s) race and/or nationality by the RNM while performing the MSM is crucial to properly perform their statutory task and that this task cannot be performed based on decisions based only on neutral criteria and non-protected characteristics. Having said this, it is clear that allowing this in practice will cause many problems, especially with regard to proving that race and/or nationality were indeed part of a composed range of factors leading up to the decision to stop and search a vehicle or a person and not the only reason. As illustrated by the excerpts from the fieldwork, there are strong stereotypes amongst street-level RNM officials with regard to the involvement of certain populations in behaviours that would fall within the legal mandate of the MSM. And in practice it can be difficult to establish to what extent a decision is predominantly - and initially - fuelled by these stereotypes after which street-level RNM officials will also try to find other factors to support their decision, or whether the decision is indeed based on a more holistic assessment in which race and/or nationality are just one of many factors that are taken into consideration. It remains to be seen what the Dutch Court will decide and how they will motivate their decision.

\section{Concluding Reflections}

As observed by Carrera, 'crises' are well known to serve as political catalysts for the adoption of previously existing and controversial ideas, offering new momentum for their expedited adoption in the name of emergency. ${ }^{68}$ The so-called European migration crisis definitely seemed to have served that purpose and it remains to be seen to what extent the global Corona-crisis will also leave its mark on migration and border control. Some critics are saying that it might even be the end of Schengen as we know it.

What this chapter has illustrated is that the Schengen as we know it, has always been less 'open' than its main underlying principle - the principle of free movement - implied it was. The mobility of people has always been securitised

\footnotetext{
${ }^{68} \mathrm{~S}$ Carrera, 'The 20 Years Anniversary of the Tampere Programme: Securitization, Intergovernmentalism and Informalization' (2010) 27(1) Maastricht Journal of European and Comparative Law 3-9.
} 
and therefore monitored. Whereas this might not have been very visible before, the European migration crisis has made it clear that Member States are willing to go 'all out' in an attempt to protect their borders against unwanted others. A rhetoric of exclusion and othering underpins European and national debates on mobility, leading to the further blurring and fusion of functional, normative and discursive barriers between crime control and immigration control.

The blurring of the boundaries between crime control and immigration control - and the ways in which that subsequently affects the actions of street-level immigration and border officials - is illustrated by the analysis of the MSM in the Netherlands. The proactive discretionary power to stop a vehicle or a person to check whether or not they are entering the Netherlands with a valid status - so 'legally' - creates room for 'crimmigrant' stereotypes to roam freely. The Dutch case illustrates that - like in other countries - 'nationality' and 'ethnicity' have become proxies for race, for focusing on the non-native 'other'. Whereas this is a problematic observation from the standpoint of non-discrimination, it touches upon a more fundamental question: the question whether measures of immigration and border control in a time where migration is highly securitised, politicised and mediatised can in fact be enforced without such stereotypical images playing a role at all.

Current times and current crises force us to rethink the notion of Schengen as well as perhaps the notion of Europe. Whereas the idea behind the European Union is said to be solidarity, again, the increased emphasis on security seem to take Member States in another direction: one of national sovereignty and the preservation of national identity in which there might not even be the need for article 23 SBC checks anymore. 
